\title{
COMPARATIVE EFFECTS OF SYNTHETIC LYSINE AND METHIONINE SUPPLEMENTS ON PERFORMANCE AND CARCASS CHARACTERISTICS OF FINISHER BROILERS FED CORN-SOYBEAN BASED DIETS
}

\author{
Victoria Nnenna MEREMIKWU ${ }^{\star 凶}$ and Peter Noah GBOSHE \\ Department of Animal Science, Faculty of Agriculture and Forestry, Obubra Campus, Cross River University of Technology, PMB 112, Cross River \\ State Nigeria \\ Email: victoriameremikwu@yahoo.com; (D) ORCiD: 0000-0002-3904-8234 \\ Supporting Information
}

\begin{abstract}
The aim of this research was to investigate the effects of lysine and methionine supplements in corn-soybean meal diets for finisher broilers, by comparing their combined and sole effects on performance and carcass characteristics of the birds. Parameters measured were performance (body weight, weight gain, feed intake, feed conversion ratio and mortality), dressed weight, dressing percentage, carcass cuts and internal organs. The experimental diets were: T1 (control) = lysine + Methionine, T2 (sole lysine) and T3 (sole methionine) supplements. Final body weight, weight gain, carcass and carcass cuts were significantly higher in the control (lysine + methionine) than in the sole supplemented diets, while sole supplementation with methionine (T3) produced significant higher values than sole lysine (T2) in the above mentioned parameters The liver was significantly enlarged in the birds that received the sole supplemented diets. Due to the enlarged liver of the birds fed the sole supplemented diets, it was concluded that supplementation with both lysine and methionine is indispensable in corn- soybean meal based diets for finisher broilers.
\end{abstract}

Keywords: Amino acid, Broiler, Lysine, Methionine, Supplement.

\section{INTRODUCTION}

Broilers are domestic chickens (Gallus domesticus) of either sex, specially bred for rapid growth and meat production, commercially. They reach an average live weight of 2.2 to $2.8 \mathrm{~kg}$ at 5 to 8 weeks of age on consumption of 3.3 to $5.0 \mathrm{~kg}$ of feed depending on the nutrient content of the diet (Smith, 2001). Broiler production involves two phases in a production cycle namely; a "starter phase" from day one to week four of age, on a starter diet of $22-24 \%$ crude protein (CP) and a "finisher phase" from week four to week eight of age on a finisher diet of $19 \%$ CP (Aduku, 2004). Meremikwu and Gboshe (2007) reported an average feed intake of $130.8 \mathrm{~g} / \mathrm{bird} /$ day during the finisher phase against the $45.0 \mathrm{~g} / \mathrm{bird} / \mathrm{day}$ at the starter phase. This resulted to high cost of feed/kg weight gain at the finisher phase (Meremikwu and Gboshe, 2007; Tandoğan and Çiçek, 2016). Although feed intake is very high at the finisher phase growth rate is also very high. Smith (2001) reported that the peak growth rate for the broiler is achieved between five to eight weeks of age. This is about $64.0 \mathrm{~g} /$ day against $31.0 \mathrm{~g} /$ day at the starter phase (Meremikwu and Gboshe, 2007).

Protein is a vital nutrient in poultry nutrition because of its biological role in enhancing growth, egg production, immunity and adaptation to environment (Esmnil, 2016). The biological function of protein is attributed to specific amino acids (Lee et al., 2020). Lysine and methionine have universally been recognized as the limiting amino acids in most of the practical diets for broilers especially in diets base on corn and soybean meals which are the basal ingredients in most poultry diets (Farkhoy et al., 2012; Lee et al., 2020). Dietary deficiencies of lysine and methionine have been shown to impair chicken growth. Wen et al. (2014) reported that broilers fed methionine deficient diet exhibited low concentration of insulin-like growth factor 1 (IGF-1) within two days of the feeding, which resulted to low performance and low breast muscle growth. Cacew et al. (2005) reported that Lysine deficient diet increased fat synthesis at the expense of body protein accretion and energetic efficiency in broilers.

The supplementation of poultry feeds with Lysine and methionine in crystalline form is very common in the poultry industry. Fishmeal is also described as an excellent source of high quality protein in cereal - based diet for poultry because of the natural balance of essential nutrients including high content of lysine and methionine. However, the use of fish meal in most developing countries is limited by cost. Fishmeal is also reported to be a source of food-borne pathogen especially salmonella specie (Novoslavskij et al., 2016). Research has shown that industrial amino acids are competitively available and can replace protein sources in poultry diets to match amino acid requirements (Farrell, 2005). According to Farrell (2005), little or no-dietary protein sources can be used in poultry diets because protein sources are both scarce and expensive and nitrogen excretion is high.

This research was designed to investigate the basic traits (essentialities) of lysine and methionine supplements in corn - soybean meal based diets for finisher broilers by comparing their combined and sole effects on performance and carcass characteristics of finisher broilers. Parameters measured were performance (body weight, body weight gains, feed intake, feed conversion ratio and mortality), dressed weight, dressing percentage, carcass cuts and internal organs. 


\section{MATERIALS AND METHODS}

\section{Experimental site}

The study was carried out at the Teaching and Research Farm of the Department of Animal Science, Faculty of Agriculture and Forestry, Obubra Campus, Cross River University of Technology (CRUTEH), Cross River State Nigeria. The location of the study lies along Latitude 6" 4.6032' N and Longitude 8" 19.9446' East (Date and Time Information, 2020).

\section{Experimental treatments and design}

The experiment comprised three treatments each of which was replicated four times in a Complete Randomized Design (CRD). The treatments are as follows: $T_{1}$ (control): Methionine and Lysine; $T_{2}$ : Lysine only; $T_{3}$ : Methionine only.

\section{Experimental diets}

The feed ingredients used for the diets were based on availability and cost. The cheapest and most available ingredients were used in formulation of the diets. They include; maize, Soybean meal, wheat offal, bone meal, mineral/vitamin premix, synthetic lysine and methionine and common salt. The diets were formulated according to NRC 1994 specification. The experimental diets and their calculated chemical composition are presented in table 1. The chemical composition of the rations was obtained by calculation. The calculation was carried out using the spreadsheet method as described by Smith (2001).

\begin{tabular}{|c|c|c|c|}
\hline Ingredients (\%) & $\begin{array}{c}\mathrm{T}_{1} \text { (control) } \\
\text { Methionine + Lysine }\end{array}$ & $\begin{array}{c}\mathrm{T}_{2} \\
\text { Lysine }\end{array}$ & $\begin{array}{c}\mathrm{T}_{3} \\
\text { Methionine }\end{array}$ \\
\hline Maize & 48.94 & 49.26 & 49.26 \\
\hline Soybean meal & 36.56 & 36.49 & 36.49 \\
\hline Wheat offal & 10.00 & 10.00 & 10.00 \\
\hline Bone meal & 3.25 & 3.25 & 3.25 \\
\hline Common salt & 0.25 & 0.25 & 0.25 \\
\hline Vitamin premix* & 0.50 & 0.50 & 0.50 \\
\hline DL-methionine & 0.25 & 0 & 0.25 \\
\hline Lysine - Hcl & 0.25 & 0.25 & 0 \\
\hline Total & 100.00 & 100.00 & 100.00 \\
\hline \multicolumn{4}{|c|}{ Calculated composition of experimental diets. } \\
\hline Crude protein (\%) & 20.00 & 20.00 & 20.00 \\
\hline ME (Kcal/kg) & 3073.10 & 3081.77 & 3081.77 \\
\hline Crude fibre (\%) & 3.99 & 4.00 & 4.00 \\
\hline Methionine (\%) & 0.98 & 0.32 & 0.57 \\
\hline Lysine (\%) & 1.58 & 1.33 & 1.08 \\
\hline
\end{tabular}

\section{Management of experimental animals}

One hundred and twenty finisher broilers were used for the feeding trial which lasted for twenty-eight days. The birds were selected after brooding and randomly allotted to the twelve experimental units (10 birds per unit). They were housed in deep litter house partitioned into experimental units of $8 \mathrm{ft} \times 12 \mathrm{ft}$ (width $\times$ length). Feed and water were given ad libitum. The birds were managed using standard husbandry practices for rearing broilers.

\section{Data collection}

The birds were weighed at the beginning of the experiment to get their initial body weight. They were weighed thereafter on weekly basis. Weight gain and feed conversion ratio were deduced from the weekly body weights. Feed offered daily was weighed and the left over weighed the following morning. Feed intakes were obtained by subtracting the leftover from the quantity supplied the previous day. At the end of the experiment at eight weeks of age, four birds were randomly selected from each treatment for carcass analysis. The birds were starved of feed but not water for twelve hours before slaughtering. The slaughtering and dressing of the birds were carried out using standard practices for processing broilers.

\section{Statistical analysis}

Data collected were subjected to analysis of variance (ANOVA) using Minitab Statistical Package. Significant means were separated using the Fisher Least Significant Difference (FLSD) that is containing in the statistical software. 


\section{Ethical approval}

Birds were handled and managed in accordance with rules and recommendations in the "Guide for the Care and use of Animals", presented in the Faculty of Agriculture and Forestry Obubra Campus, Cross River University of Technology, Cross River State, Nigeria (ethical committee).

\section{RESULTS AND DISCUSSION}

The calculated chemical composition of the experimental diets are presented in table 1 , while the results of the performance and carcass characteristics of the experimental birds are presented in tables 2 and 3 , respectively.

\section{Experimental diets}

The limitations of Lysine and methionine in corn-soybean meal diets for this experiment are revealed in the calculated chemical composition of the diet in table 1 . The calculated lysine levels of all the diets including sole methionine diet (T3) were up to minimum requirement for finisher broilers, while the methionine levels in the sloe lysine diet (T2) was below minimum requirement (NRC, 1994). This result has revealed that methionine is the first limiting amino acid in corn-soybean meal based diets for broilers. This is supported by the report of Byrne (2018) that methionine is the first limiting essential amino acid in corn-soybean meal based diets for broilers.

\section{Performance}

The final body weights and body weight gains of the experimental birds differed significantly $(P<0.05)$ between the treatments and were highest $(P<0.05)$ in the control $(\mathrm{T} 1$, Lys + Meth) and lowest $(P<0.05)$ in the sole lysine $(T 2)$. The sole methionine group (T3) were in-between the control and the sole lysine groups in the said parameters i.e. lower $(P<0.05)$ than the control and higher $(P<0.05)$ than the sole lysine. Feed intake did not differ $(P<0.05)$ between the treatments. Feed conversion ratio followed the same trend with body weight and body weight gain, being highest $(P<0.05)$ in the control and lowest $(P<0.05)$ in the sole lysine group. Mortality was zero percent for all the treatments. The significant $(P<0.05)$ higher performance of the control birds (T1, Lysine + methionine) over the sole lysine (T2) and sole methionine (T3) could be due to complementary effect of the amino acids to each other. This is supported by the report of Si et al. (2001 and 2014) that there were no interaction between Lysine and Methionine when they were fed equal to or in excess of NRC recommendations in broiler diets. Rather, each of the amino acids supplied a complimentary effect to meet specific deficiencies. The significant $(\mathrm{P}<0.05)$ low performance of the sole lysine birds $(\mathrm{T} 2)$ in comparison to the sole methionine birds (T3) could be due to absence of complimentary effect of methionine and it is an indication that methionine is the first limiting essential amino acid in corn-soybean meal diet for broilers. This is also supported by the report of Neutkens (2005) that DL-methionine or Methionine hydroxyl is the first-limiting amino acid for birds, while Lysine is the first-limiting amino acid in corn-soybean meal based diet for pigs. According to Neutkens (2005), to use crystalline amino acids in low- protein diets effectively, and to minimize nitrogen excretion, you must first understand their limitation i.e. the order in which they are limiting in various feedstuffs, and second the magnitude of difference between them. The absence of supplemental Methionine in the sole Lysine diet (T2) reduced the methionine content of the diet below minimum requirement as revealed in the calculated chemical composition of the diets in table 1 , resulting to poor performance of the birds.

\section{Table 2 - Performance of finisher broilers fed supplemented diets (lysine and methionine).}

\begin{tabular}{|c|c|c|c|c|}
\hline Treatments & $\begin{array}{l}T_{1} \text { (control) } \\
\text { Meth + Lys }\end{array}$ & $\begin{array}{c}T_{2} \\
\text { (Lys) }\end{array}$ & $\begin{array}{c}T_{3} \\
\text { Meth }\end{array}$ & SEM \\
\hline Initial body weigh t (kg) & 0.62 & 0.62 & 0.62 & - \\
\hline Final body weight (kg) & $2.80^{a}$ & $2.15^{c}$ & $2.50^{b}$ & 0.13 \\
\hline Weight gain (g/day) & $77.86^{a}$ & $54.64^{c}$ & $67.14^{b}$ & 4.59 \\
\hline Feed-intake (g/day) & 127.00 & 130.75 & 128.50 & $5.424 n s$ \\
\hline FCR ( $g$ of feed/g of gain) & $1.63^{c}$ & $2.40^{a}$ & $1.92^{b}$ & 012 \\
\hline Mortality (\%) & 0.00 & 0.00 & 0.00 & 0.12 \\
\hline
\end{tabular}

\section{Carcass and carcass cuts}

The results of carcass and carcass cuts followed the same trend with that of performance parameters. The control birds $(\mathrm{T} 1$, Lys + Meth) had significant $(\mathrm{P}<0.05)$ higher values for carcass parameters (including dressed weight, dressing percentage, breast and thigh) than the birds in treatments T2 and T3 (sole lysine and sole methionine, respectively) table 3. The sole lysine birds (T2) had the lowest $(P<0.05)$ values in carcass parameters mentioned above, while the sole methionine birds (T3) were in-between the control (Lys + meth) and the sole Lysine birds (T2) in the said parameters. The significant $(\mathrm{P}<0.05)$ higher carcass values of the control birds (Lys + Meth) over the sole lysine and sole methionine birds confirm the complimentary effect of the two amino acids to each other to meet specific deficiencies and enhance the 
productivity of birds as reported by Zhai et al. (2016). The significant $(P<0.05)$ higher performance of the sole methionine (T3) over the sole lysine groups (T2) in body weight and body weight gains reflected in significant $(P<0.05)$ higher breast and thigh values. This is supported by the report of Wen et al. (2014) that methionine increased the concentration of insulin-like growth factor in broilers with subsequent improvement in performance and breast muscle growth. The significant $(\mathrm{P}<0.05)$ lower carcass values of the sole Lysine birds (T2) in comparison to the sole Methionine birds (T3) could be due to the low dietary content of methionine in the sole lysine diet as revealed in the calculated chemical composition of the diets in table 1.

\section{Table 3 - Carcass and Internal organ weights of finisher broilers fed supplemental lysine and methionine}

\begin{tabular}{|c|c|c|c|c|}
\hline $\begin{array}{ll}\text { Parameters }(\mathrm{g}) & \text { Treatments } \\
\end{array}$ & $\begin{array}{l}T_{1} \text { (control) } \\
\text { Meth + Lys }\end{array}$ & $\begin{array}{c}T_{2} \\
\text { (Lys) }\end{array}$ & $\begin{array}{c}T_{3} \\
\text { Meth }\end{array}$ & SEM \\
\hline Pre-slaughter weight (kg) & $2.80^{a}$ & $2.15^{c}$ & $2.50^{\mathrm{b}}$ & 0.102 \\
\hline Dressed weight (kg) & $2.00^{a}$ & $1.30^{c}$ & $1.55^{b}$ & 0.104 \\
\hline Dressing percentage (\%) & $71.43^{a}$ & $60.47^{c}$ & $62.00^{b}$ & 1.86 \\
\hline \multicolumn{5}{|l|}{ Carcass cuts (\% of pre-slaughter weight) } \\
\hline Drumstick & 10.73 & 9.26 & 9.96 & $1.96^{\mathrm{ns}}$ \\
\hline Breast/wing & $37.67^{a}$ & $29.13^{c}$ & $34.91^{b}$ & 1.43 \\
\hline Thigh & $12.24^{a}$ & $11.04^{c}$ & $11.96^{b}$ & 0.192 \\
\hline Back & $10.89^{a}$ & $10.04^{c}$ & $10.99 a$ & 0.27 \\
\hline \multicolumn{5}{|l|}{ Internal organ (\% of pre-slaughter weight) } \\
\hline Gizzard & 2.50 & 2.53 & 2.51 & $0.07^{\mathrm{ns}}$ \\
\hline Heart & 1.09 & 1.10 & 1.10 & $0.026^{\text {ns }}$ \\
\hline Liver & $1.96^{b}$ & $2.21^{a}$ & $2.20^{a}$ & 0.053 \\
\hline Abdominal fat & $1.27^{b}$ & $1.28^{a}$ & $1.27^{b}$ & $0.168^{n s}$ \\
\hline
\end{tabular}

\section{Table 4 - Economics of supplementation with lysine and methionine in broiler nutrition.}

\begin{tabular}{|c|c|c|c|c|c|c|c|}
\hline \multirow{2}{*}{ Ingredients } & \multirow{2}{*}{$\begin{array}{l}\text { Unit cost } \\
(\mathbf{A})^{*}\end{array}$} & \multicolumn{3}{|c|}{ Quantity/100kg of feed } & \multicolumn{3}{|c|}{ Amount ( $\mathrm{N} / 100 \mathrm{~kg}$ of feed) } \\
\hline & & $T_{1}$ (Control) & $\mathbf{T}_{2}$ (Lys) & $\mathbf{T}_{3}$ (Met) & $\mathbf{T}_{1}$ & $T_{2}$ & $\mathbf{T}_{3}$ \\
\hline Lysine & 1,500 & 0.25 & 0.25 & 0.00 & 375 & 375 & 0 \\
\hline Methionine & 1,500 & 0.25 & 0.00 & 0.25 & 375 & 0 & 375 \\
\hline Total cost ( & & & & & 750 & 375 & 375 \\
\hline $\begin{array}{l}\text { Cost of supplementation / } \mathrm{kg} \text { of feed (Total } \\
\text { cost divide by } 100)(\mathbb{N})\end{array}$ & & & & & 7.50 & 3.75 & 3.76 \\
\hline Cost/kg of feed (A) & & & & & 159.5 & 155.75 & 155.75 \\
\hline Feed conversion ratio (FCR) & & & & & 1.63 & 2.40 & 1.92 \\
\hline Cost of supplementation/kg weight gain ( $\mathrm{N}$ ) & & & & & 12.25 & 9.00 & 9.00 \\
\hline Cost of feed/kg weight gain( $\mathbb{N}$ ) & & & & & 260.0 & 373.8 & 299.04 \\
\hline Relative cost of feed/kg weight gain (\%) & & & & & $27 ; 87$ & 40.07 & 32.05 \\
\hline
\end{tabular}

\section{Internal organs}

There was no significant difference $(\mathrm{P}<0.05)$ between the treatments in the sizes of the internal organs, apart from the liver that was significantly $(P<0.05)$ larger in the sole lysine and the sole methionine birds in comparison with the control (lys + met). The significant $(P<0.05)$ larger sizes of liver in the sole lysine (T2) and sole methionine (T3) birds could be due to increased metabolic activities to cope with imbalance of the amino acids. This is supported by the report of Park (2006) that one of the biochemical responses of animals fed amino acid imbalance diets is an increase in the activities of 
the enzymes involved in the catabolism of the limiting amino acid leading to increase in liver size. This is supported by the reports of Zaefarian et al. (2019) that increased liver size in avian is considered a positive indicator associated with higher metabolic activity and higher energy expenditure.

\section{Economics of supplementation with lysine and methionine}

The result of economics of supplementation with lysine and methionine is presented in Table 4. The birds fed the sole supplemented diets had about 4.18 - 12.2\% higher cost of feed/kg weight gain than the control even though the cost of supplementation was higher in the control than the sole supplemented. The higher cost of feed/kg weight gain exhibited by birds in the sole supplemented diets (T1 and T2) could be due to poor utilization of feed by these birds. This is supported by the fact that the enlarged liver of the birds in the sole supplemented diets is associated with increased metabolic activities and higher energy expenditure (Zaefarian et al., 2019).

\section{CONCLUSION}

From the results of this study, it was observed that supplementation with both lysine and methionine produced significant enhanced effect than sole supplementation. Sole lysine supplementation produced significant $(P<0.05)$ lower values in all parameters measured including performance, carcass and carcass cuts compared to sole methionine supplementation. Sole supplementations with either lysine or methionine caused increase in liver size. Although sole methionine supplementation gave significant $(P<0.05)$ enhanced effects than sole lysine, it was concluded from this research that supplementation with both lysine and methionine is essential in corn-soybean meal based diet for finisher broilers to avoid increased catabolic activities that result to enlarged liver in the birds.

\section{DECLARATION}

\section{Corresponding author}

Victoria N. Meremikwu, Ph.D., Department of Animal Science, Faculty of Agriculture and Forestry, Obubra Campus, Cross River University of Technology, Cross River State, Nigeria. Email: victoriameremikwu@yahoo.com.

\section{Availability of data}

Data can be availed to the journal upon request.

\section{Consent to publish}

Not applicable.

\section{Conflict of interest}

The authors declare that they have no competing interest.

\section{REFERENCES}

Aduku AO (2004). Animal nutrition in the tropics: Feed and feeding, pasture management, monogastric and ruminant nutrition. Zavcon Computer and Business Bureau, Zaria. 17. Google Scholar

Carew L, McMurtry J, Alster F (2005). Effects of lysine deficiencies on plasma levels of thyroid hormones, insulin-like growth factors I and II, liver and body weights, and feed intake in growing chickens. Poultry Science. 84(7): 1045-50. Article link I https://doi.org/10.1093/ps/84.7.1045

Date and Time information (2020). Geographical coordinates of Obubra in Degrees and Minutes. Article link

Esmnil S (2016). Understanding protein requirements. Nutrition-Poultry World. Article link

Farkhoy M, Modirsanei M, Ghavidel O, Sadegh M, Jafarnejad S. (2012). Evaluation of protein concentration and limiting amino acids including lysine and met+ cys in prestarter diet on performance of broilers. Veterinary Medicine International, 2012: 394189. Article link I https://doi.ordg/10.1155/2012/394189.

Farrel DJ (2005). Matching poultry production with available feed resources. World's Poultry Science Journal, 61(2): 298307. Article link | DOI: https://doi.org/10.1079/wps200456

Lee CY, Song AA, Loh TC, and Abdul Rahim R (2020). Effects of lysine and methionine in a low crude protein diet on the growth performance and gene expression of immunity genes in broilers. Poultry Science, 99(6): 2916-2925. Article link I https://doi.org/10.1016/j.psj.2020.03.013

Meremikwu VN and Gboshe P (2007). Comparative evaluation of the effects of Brooding and Finishing variables on the productive life of the broiler. Animal Production Research Advances, 3(2): 143-147. Article link I https://doi.org/10.4314/apra.v3i2.36382

Minitab Statistical Software (2014). Volume 16. Minitab Inc. PA. USA.

Neutkens D (2005). Amino Acid and their limitations/National Hog Farmers. Article link 
Novoslavskij A, Terentjeva M, Eizenberga I, Valciṇa 0, Bartkevičs V, and Bērziṇš A (2016). Major foodborne pathogens in fish and fish products: a review. Annals of Microbiology, 66(1): 1-15. Article link I https://doi.org/10.1007/s13213 $\underline{015-1102-5}$

NRC (National Research Council) (1994). Nutrition Requirements of Poultry, 9th edition. National Academy of Science, National Academy Press, Washington DC. Article link I

Park BC (2006). Amino acid imbalance-biochemical mechanism and nutritional aspects. Asian-Australians Journal of Animal Science, 19(9): 1361-1368. Article link

Si J, Fritts CA, Burnham DJ and Waldroup PW. (2001). Relationship of dietary lysine level to the concentration of all essential amino acids in broiler diets. Poultry Science, 80(10): 1472-1476. Article link I https://doi.org/10.1093/ps/80.10.1472

Si J, Fritts CA. Kersey JH and Waldroup PW (2004). An evaluation of the Interaction of lysine and methionine in diets for growing broilers. International Journal of Poultry Science, 3(1): 51-60. Article link I https://dx.doi.org/10.3923/ijps.2004.51.60

Smith AJ (2001). Poultry. CTA Tropical Agriculturalist series. Macmillan Education Limited, London and 0xford, pp. 1-242. Article link I https://publications.cta.int/publications/publication/244/

Tandoğan M, and Çiçek H (2016). Technical performance and cost analysis of broiler production in Turkey. Brazilian Journal of Poultry Science, 18(1): 169-174. Article link I https://doi.org/10.1590/18069061-2015-0017

Wen C, Wie P, Chen Y, Wang T, and Zhou Y (2014). Methionine improves the Performance and breast muscle growth of broilers with lower hatching weight by altering the expression of genes associated with the insulin-like growth factor signaling pathway. British Journal of Nutrition, 111(2): 201-206. Article link I https://doi.org/10.1017/S0007114513002419

Zaefarian F, Abdollahi MR, Cowieson A, and Ravindran V (2019). Avian liver: The Forgotten organ. Animals, 9(2): 63. Article link I https://doi.org/10.3390/ani9020063

Zhai W, Schilling MW, Jackson V, Peebles ED, Mercier Y (2016). Effects of dietary lysine and methionine supplementation on Ross 708 male broilers from 21 to 42 days of age (II): breast meat quality. Journal of Applied Poultry Research. 25(2):212-22. Article link I https://doi.org/10.3382/japr/pfw003 